\title{
FAKTOR YANG BERHUBUNGAN DENGAN KEJADIAN COMPUTER VISION SYNDROME (CVS) PADA PEGAWAI PT. MEDIA KITA SEJAHTERA KENDARI
}

\section{FACTORS RELATED TO THE EVENT OF COMPUTER VISION SYNDROME (CVS) IN THE STAFF OF PT. OUR PROSPEROUS MEDIA KENDARI}

\author{
Arum Dian Pratiwi ${ }^{1 *}$, Aulya Safitri ${ }^{2}$, Junaid, Lisnawaty ${ }^{3}$ \\ Fakultas Kesehatan Masyarakat Universitas Halu Oleo \\ Kambu, Kendari City, South East Sulawesi 93561 \\ Email : arum.dian28@gmail.com
}

\begin{abstract}
Computer Vision Syndrome (CVS) is a term used to describes a collection of symptoms such as tension on the eyes, eyes discomfort, headaches, dry eyes, blurred vision at close range, and double vision which occurs on the user's computer. This study aimed to determine the factors associated with CVS incidents in PT. Media Kita Sejahtera. This study was a quantitative study using descriptive analytic method with cross sectional study design. The samples in this study were all employees of computer users at PT. Media Kita Sejahtera Kendari, amounting to 35 people. Data analysis used were univariate analysis and bivariate analysis. The results of this study indicated that there was a relationship between computer usage time $(\rho$-value $=0,000)$, rest period $(\rho$ value $=0.004)$ with CVS on staffs of computer user at PT. Media Kita Sejahtera Kendari, there was no relationship between gender $(\rho$-value $=0.056)$, use of glasses $(\rho$-value $=0.629)$, view distance $(\rho$ value $=1,000)$ with CVS in staffs of computer users at PT. Media Kita Sejahtera Kendari. The suggestion of this study is that every 20 minutes working in front of the computer is expected to rest \pm 20 seconds by looking at objects that are \pm 20 feet apart to prevent CVS. For other researchers to be able to examine other variables such as age, object size, duration of use of VDT (including tablets), monitor screen displays, types of respondent activities, and so on.
\end{abstract}

Kata Kunci: Computer Vision Syndome; Use of Glasses; Computer Usage Time; View Distance

\begin{abstract}
ABSTRAK
Computer Vision Syndrome (CVS) adalah sebuah istilah yang digunakan untuk menjelaskan kumpulan gejala berupa rasa tegang pada mata, rasa tidak nyaman pada mata, sakit kepala, mata kering, penglihatan buram pada jarak dekat, dan penglihatan ganda yang terjadi pada pengguna komputer. Penelitian ini bertujuan untuk mengetahui faktor yang berhubungan kejadian CVS pada pegawai PT. Media Kita Sejahtera. Penelitian ini merupakan penelitian kuantitatif dengan menggunakan metode deskriptif analitik dengan rancangan penelitian cross sectional. Populasi dalam penelitian ini adalah semua pegawai pengguna komputer di PT. Media Kita Sejahtera Kendari yang berjumlah 35 orang. Analisis data yang digunakan adalah analisis univariat dan analisis bivariat. Hasil penelitian ini menunjukan bahwa terdapat hubungan antara lama penggunaan komputer $\left(p_{\text {value }}=0,000\right)$, lama istirahat $\left(p_{\text {value }}=\right.$ $0,004)$ dengan kejadian CVS pada pegawai pengguna komputer di PT. Media Kita Sejahtera Kendari, sementara tidak terdapat hubungan antara jenis kelamin $\left(p_{\text {value }}=0,056\right)$, penggunaan kacamata $\left(p_{\text {value }}=0,629\right)$, jarak mata $\left(p_{\text {value }}=1,000\right)$ dengan kejadian CVS pada pegawai pengguna komputer di PT. Media Kita Sejahtera Kendari. Saran adalah setiap 20 menit bekerja di depan komputer diharapkan beristirahat \pm 20 detik dengan melihat benda yang jaraknya \pm 20 kaki untuk mencegah terjadinya CVS. Untuk peneliti lainnya agar dapat meneliti variabel lain seperti usia, ukuran obyek, lama penggunaan VDT (termasuk tablet), tampilan layar monitor, jenis kegiatan responden, dan sebagainya.
\end{abstract}

Kata Kunci: Computer Vision Syndrome; Penggunaan Kacamata,; Lama Penggunaan Komputer; Jarak Pandang 


\section{PENDAHULUAN}

Penggunaan computer di era Revolusi Industri 4.0 adalah suatu hal yang biasa. Hampir semua jenis pekerjaan membutuhkan komputer. Sebagai alat bantu yang paling banyak digunakan manusia, komputer ternyata juga dapat menimbulkan penyakit akibat kerja. Monitor komputer tidak hanya menampilkan gambar dan teks, tetapi juga mengeluarkan radiasi gelombang yang tidak dapat dideteksi oleh mata seperti sinar (UV) dan sinar $\mathrm{X}$ yang dapat menyebabkan gangguan fisiologis pada mata, kepala, ataupun badan(1). Penggunaan computer yang terlalu lama dapat menyebabkan gangguan pada penglihatan. Gangguan tersebut dapat berupa Computer Vision Sindrome (CVS). Salah satu gejala CVS adalah kelelahan mata. Kelelahan mata terjadi akibat penggunaan fungsi penglihatan secara intensef sehingga memicu penurunan ketahanan penglihatan(2).

American Optometric Association (AOA) mendefinisikan CVS sebagai kumpulan gejala pada mata dan penglihatan yang berhubungan dengan aktivitas yang memberatkan penglihatan jarak dekat dan berlangsung selama atau setelah penggunaan komputer, tablet, e-reader, dan telepon seluler (AOA, 2017). Hingga $90 \%$ pengguna computer dapat mengalami gejala visual termasuk kelelahan mata, sakit kepala, ketidaknyamanan mata, mata kering, diplopia, dan kekaburan. Prevalensi gejala visual meningkat secara signifikan pada individu yang menghabiskan lebih dari 4 jam setiap hari bekerja di depan layar/monitor computer (3).

Meenurut WHO pada tahun 2010 terdapat 285 juta orang atau 4,24\% dari total populasi di dunia mengalami gangguan penglihatan dengan distribusi 39 juta orang menderita kebutaan, 246 juta orang di dunia mengalami low vision, dan $82 \%$ mengalami gangguan penglihatan (4). Hasil penelitian yang dilakukan oleh Darmaliputra (2019), dari 123 mahasiswa jurusan teknologi informasi Universitas Udayana sebagai responden, $74 \%$ mengalami CVS dan $26 \%$ sisanya tidak mengalami CVS. Hal serupa juga ditemukan oleh Permana (2015) yang meneliti keluhan CVS pada pekerja rental computer di wilayah UNNES menemukan bahwa 30 responden (83\%) mengalami keluhasn CVS dan 6 responden sisanya (17\%) tidak mengalami keluhan CVS(5). salah satu perusahaan yang memanfaatkan teknologi elektronik berupa komputer adalah PT. Media Kita Sejahtera. Perusahan tersebut lebih dikenal dengan nama Kendari Pos oleh masyarakat Kota Kendari. Kendari Pos adalah salah satu media pencetak surat kabar Nasional pertama di Sulawesi Tenggara. PT. Media Kita Sejahtera memiliki 35 orang yang menggunakan teknologi komputer, di antaranya bidang umum, redaksi, bidang keuangan, bidang even dan promosi, bidang iklan, dan bidang sirkulasi atau pendistribusian koran. Dengan begitu pekerja yang bekerja di beberapa bidang tersebut dapat menghabiskan waktu yang lama di depan komputer dimana mata menjadi salah satu organ tubuh yang sangat digunakan. Hasil survey awal diperoleh informasi bahwa pekerja umum, bidang keuangan, bidang even dan promosi, dan bidang sirkulasi atau pendistribusian koran menghabiskan waktu di depan komputer paling lama 7 jam perhari sedangkan redaksi, dan bidang iklan bisa menghabiskan waktu selama 8 jam per harinya, jika ada deadline mereka bisa menghabiskan waktu 24 jam di dapan komputer.

Komputer sebagai alat bantu yang banyak digunakan manusia, ternyata juga menimbulkan penyakit akibat kerja seperti halnya pemakaian mesin pada industri. Selain menampilkan gambar dan teks, monitor komputer juga mengeluarkan radiasi dan gelombang yang tidak dapat dideteksi oleh mata seperti sinar ultraviolet (UV) dan sinar X. Menurut John E. Batubara, radiasi komputer yaitu sinar $X$ dapat menyebabkan gangguan fisiologis pada mata, jika mata terpapar dalam waktu yang lama (6)

Mata normal dapat melihat fokus pada gambar yang memiliki sudut tegas dengan latar belakang warna dan kontras yang baik antara latar belakang dan tulisan. Cara melihat gambar yang ada di layar komputer berbeda dengan melihat gambar yang dicetak di kertas, karena pada layar komputer menggunakan kumpulan titik kecil yang disebut piksel. Masing-masing piksel memancarkan cahaya terang di bagian tengah namun berangsur gelap di bagian pinggirnya. Hal ini menyebabkan mata normal tidak dapat fokus melihat gambar tersebut, melainkan fokus pada satu titik dibelakang layar yang disebut sebagai resting point of accomodation (RPA) atau "fokus gelap". Kerja mata yang seperti ini secara terus menerus menyebabkan timbulnya gejalagejala CVS(7).

Frekuesi berkedip, normalnya adalah 16-20 kali per menit. Studi menunjukkan frekuensi 
berkedip menurun hingga 6-8 kali per menit pada pekerja yang menggunakan computer. Memaksa mata untuk focus dalam jarak dekat untuk waktu yang lama memaksa kerja dari otot siliaris pada mata. Umur sekitar 30-40 tahun dilaporkan mengeluhkan ketidakmampuan dalam memfokuskan obyek-obyek dekat setelah bekerja dalam waktu singkat, yang berakhir pada perunurnan mekanisme focus akomodasi mata dan presbyopia(8)

Adapun factor yang dapat mempengaruhi terjadinya CVS meliputi factor individu/pekerja seperti jenis kelamin, durasi bekerja di depan computer, durasi istirahat setelah menggunakan computer, penggunaan kacamata, penggunaan lensa kontak, jarak pandang, sudut pandang terhadap computer, kelainan refraksi, usia, perilaku yang berisiko, factor keturunan, lama kerja, kurangnya kedipan, penggunaan lensa kontak, adanya penyakit sistemik dan penggunaan obat-obatan; factor dari luar individu seperti pencahayaan yang tidak sesuai, cahaya yang silau, ukuran objek dari layar monitor yang sulit dibaca, kelembaban ambient rendah, pengaturan pendingin udara atau penggunaan kipas ventilasi, dan pola istirahat mata ((9); (5); (3)).

\section{BAHAN DAN METODE}

Jenis penelitian yang digunakan adalah penelitian analitik dengan pendekatan cross sectional yang bertujuan untuk mengetahui faktor yang berhubungan dengan kejadian Computer Vision Syndrome pada pegawai PT. Media Kita Sejahtera Kendari. Penelitian ini dilakukan pada bulan September 2019. Populasi dalam penelitian ini adalah semua pegawai pengguna komputer di PT. Media Kita Sejahtera Kendari berjumlah 35 orang. Seluruh populasi dijadikan sebagai sampel. Variabel dependen adalah Computer Vision Syndrome. Variabel independen adalah jenis kelamin, penggunaan kacamata, lama penggunaan komputer, lama istirahat, jarak pandang. Seluruh variabel diukur dengan menggunakan kuesioner. CVS dalam penelitian ini diukur dengan menggunakan kuesioner yang berupa pertanyaan tentang gejala CVS. Responden dikatakan mengalami CVS apabila mengalami gejala $\geq 50 \%$ dari skor jawaban yang diperoleh dan dikatakan tidak mengalami apabila skor responden $<50 \%$ dari total skor keseluruhan yaitu 28.
Analisis data yang akan digunakan adalah analisis univariat dan analisis bivariat. Analisis univariat, mempunyai tujuan untuk mendeskripsikan dari masing-masing variabel yang diteiti. Data disajikan dalam bentuk tabel dan narasi. Analisis bivariat digunakan untuk menguji hipotesis yang telah ditetapkan yaitu mempelajari hubungan antar variabel, dalam penelitian ini menggunakan $u j i$ Chi square atau uji fisher jika data yang ada tidak memenuhi syarat untuk diuji Chi square. Uji Chi Square disajikan alam bentuk tabel kontingensi $2 \times 2$ dan menggunakan komputerisasi dengan tingkat kepercayaan $95 \%(\alpha=0,05)$.

\section{HASIL DAN PEMBAHASAN}

\section{Analisa Univariat}

Tabel 1. Distribusi Responden Berdasarkan Kejadian Computer Vision Syndrom (CVS), Usia, Jenis Kelamin, Penggunaan Kacamata, Lama Penggunaan Komputer, Lama Istirahat, Jarak Mata pada Pegawai Pengguna Komputer di PT. Media Kita Sejahtera Kendari 2019

\begin{tabular}{lll}
\hline Variabel & n & $\%$ \\
\hline
\end{tabular}

\section{Computer Vision Synrome}

\begin{tabular}{lcc} 
Mengalami & 21 & 60 \\
Tidak mengalami & 14 & 40 \\
$\quad$ Usia & & \\
$\geq 28$ & 23 & 65,7 \\
$<28$ & 12 & 34,3 \\
$\quad$ Jenis Kelamin & & \\
Laki - laki & 26 & 74,3 \\
$\begin{array}{l}\text { Perempuan } \\
\text { Penggunaan Kacamata }\end{array}$ & 9 & 24,7 \\
Ya & 18 & 51,4 \\
Tidak & 17 & 41,6 \\
Lama Penggunaan & & \\
Komputer & & \\
$\geq 4$ & 23 & 65,7 \\
<4 & 12 & 34,3 \\
Lama Istirahat & & \\
$\geq 10$ & 18 & 51,4 \\
\hline$<10$ & 17 & 41,6 \\
Jarak & & \\
$\geq 50$ & 18 & 51,4 \\
\hline 50 & 17 & 48,6 \\
\hline Total & 3 & 100 \\
\hline
\end{tabular}

Berdasarkan tabel 1 diketahui bahwa sebanyak 21 responden $(60 \%)$ mengalami gejala CVS yang antara lain berupa mata lelah, tegang, mata 
nyeri, mata berair, mata teriritasi, masalah dengan lensa kontak penglihatan kabur, kesulitan dalam memfokuskan penglihatan, penglihatan ganda, presbiopia (mata tua), nyeri kepala, nyeri leher,nyeri punggung, dan nyeri bahu. Sebagian besar responden berusia $\geq 28$ tahun, yaitu sebanyak 23 responden (65,7\%). Responden paling banyak berjenis kelamin laki-laki yaitu 26 responden (74,3\%). Responden yang menggunakan kacamata ada sebanyak 18 orang (51,4\%). Lama penggunaan computer atau lama waktu yang diperlukan responden untuk bekerja di depan komputer dan tidak diselingi kegiatan lain dalam sehari adalah 65,7 $\%$ atau 23 responden menggunakan computer lebih dari 4 jam. Lama istrahat responden setelah penggunaan computer selama satu jam di depan layar komputer yang $\geq 10$ menit adalah sebanyak $51,4 \%$ (18 reponden). Jarak pandang atau jarak mata dari layar computer $(\mathrm{cm})$ yang $\geq 50 \mathrm{~cm}$ adalah $51,4 \%$ atau 18 responden.

Tabel 2. Distribusi Hubungan Usia, Jenis Kelamin, Penggunaan Kacamata, Lama Penggunaan komputer, Lama Istirahat, dan Jarak Penglihatan Dengan Kejadian Computer vision Syndrome pada Pegawai Pengguna Komputer di PT. Media Kita Sejahtera Kendari 2019.

\begin{tabular}{|c|c|c|c|c|c|c|c|}
\hline \multirow{3}{*}{ Variabel } & \multicolumn{4}{|c|}{ CVS } & \multirow{2}{*}{\multicolumn{2}{|c|}{ Total }} & \multirow{3}{*}{$\rho$-Value } \\
\hline & \multicolumn{2}{|c|}{ Mengalami } & \multicolumn{2}{|c|}{$\begin{array}{c}\text { Tidak } \\
\text { mengalami }\end{array}$} & & & \\
\hline & $\mathbf{n}$ & $\%$ & $\mathbf{n}$ & $\%$ & $\mathbf{n}$ & $\%$ & \\
\hline \multicolumn{8}{|l|}{ Jenis kelamin } \\
\hline Laki - laki & 13 & 50 & 13 & 50 & 26 & 100 & \multirow{3}{*}{0.056} \\
\hline Perempuan & 8 & 88,9 & 1 & 11,1 & 9 & 100 & \\
\hline Total & 21 & 60 & 14 & 40 & 35 & 100 & \\
\hline \multicolumn{8}{|l|}{ Penggunaan kacamata } \\
\hline Ya & 12 & 66,7 & 6 & 33,3 & 30 & 100 & \multirow{3}{*}{0,629} \\
\hline Tidak & 9 & 53,9 & 8 & 47,1 & 14 & 100 & \\
\hline Total & 21 & 60 & 14 & 40 & 35 & 100 & \\
\hline \multicolumn{8}{|c|}{ Lama penggunaan komputer (jam) } \\
\hline$\geq 4$ & 19 & 82,6 & 4 & 17,4 & 23 & 100 & \multirow{3}{*}{0.000} \\
\hline$<4$ & 2 & 16,7 & 10 & 83,3 & 12 & 100 & \\
\hline Total & 21 & 60 & 14 & 40 & 35 & 100 & \\
\hline \multicolumn{8}{|l|}{ Lama istirahat (menit) } \\
\hline$\geq 10$ & 3 & 25 & 9 & 75 & 12 & 100 & \multirow{3}{*}{0,004} \\
\hline$<10$ & 18 & 78,3 & 5 & 21,7 & 23 & 100 & \\
\hline Total & 21 & 60 & 14 & 40 & 35 & 100 & \\
\hline \multicolumn{8}{|l|}{ Jarak pandang (cm) } \\
\hline$\geq 50$ & 11 & 61,1 & 7 & 38,9 & 18 & 100 & \multirow{3}{*}{1.000} \\
\hline$<50$ & 10 & 58,8 & 7 & 41,2 & 17 & 100 & \\
\hline Total & 21 & 60 & 14 & 40 & 35 & 100 & \\
\hline
\end{tabular}

Dari tabel 2 diketahui bahwa jenis kelamin responden dikelompokkan dalam dua kategori, yaitu kelompok responden yang berjenis kelamin perempuan dan laki-laki. Secara fisiologis, lapisan tear film pada perempuan cenderung lebih cepat menipis seiring dengan meningkatnya usia. Penipisian tear film menyebabkan mata terasa kering, yang juga merupakan salah satu gejala CVS. Perbedaan fisiologis lainnya adalah penurunan sekresi air mata, perbedaan ukuranatau massa tubuh, dan fungsi hormon. Selain itu, perempuan memiliki tingkat stress yang lebih tinggi yang tidak berkaitan dengan pekerjaan, yaitu mengurus anak dan pekerjaan rumah. Perempuan juga lebih sering mendatangi pelayanan kesehatan jika merasakan suatu ketidaknyamanan pada tubuhnya(10).

Berdasarkan penelitian ini diketahui bahwa dari 35 responden, jumlah responden laki-laki $(74,3 \%)$ lebih banyak daripada responden perempuan $(24,7 \%)$. Berdasarkan hasil uji statistik, disimpulkan 
bahwa tidak ada hubungan antara jenis kelamin dengan kejadian CVS $(p=0,056)$. Hasil penelitian ini dapat terjadi karena factor usia responden yang sebagian besar berusia di bawah 40 tahun (80\%), sementara menurut Rosenfield (2011) prevalensi mata kering meningkat sesuai usia dan paling banyak terjadi pada wanita. Sehingga, karena responden paling banyak berada pada usia muda, maka tear filmnya masih berfungsi dengan baik. Di samping itu perbedaan jenis pekerjaan antara responden satu dengan lainnya menyebabkan perbedaan lama paparan dan jenis paparan. Hal ini dapat menjadi factor penyebab tidak berhubungnya jenis kelamin dengan kejadian CVS(3).

\section{HASIL DAN PEMBAHASAN}

Hasil penelitian ini sejalan dengan penelitian yang dilakukan oleh Valentina (2019) yang meneliti sindrom penglihatan computer pada mahasiswa jurusan ilmu computer. Valentina (2019) menemukan bahwa tidak ada hubungan antara jenis kelamin dengan kejadian CVS ( $\rho$-value $=0,909)$. Walaupun dalam penelitian ini juga menemukan bahwa prevalensi CVS relative lebih banyak ditemukan pada perempuan dibandingkan pada laki-laki(11).

Hal ini tidak sejalan dengan penelitian yang dilakukan oleh Anggraini dkk (2012) yang menemukan bahwa ada hubungan antara jenis kelamin dengan keluhan CVS(12). Rosenfield (2011) juga menjelaskan bahwa prevalensi mata kering meningkat dengan usia dan lebih tinggi pada wanita daripada pria. Estimasi mata kering pada wanita di atas 50 tahun adalah 7,8\% dan pada laki-laki adalah $4,3 \%$.

Kacamata digunakan untuk mengoreksi kelainan refraksi. Koreksi yang buruk merupakan salah satu risiko terjadinya mata lelah. Studi di Italia melaporkan bahwa 38\% dari pengguna Video Display Terminal (VDT) mempunyai kelainan miopia. Sebanyak $62,5 \%$ pengguna VDT dengan kacamata mengeluhkan nyeri kepala di daerah frontal yang frekuen yang merupakan salah satu akibat dari kelelahan mata akibat VDT(10).

Berdasarkan hasil uji statistik, diketahui bahwa tidak ada hubungan antara penggunaan kacamata dengan kejadian CVS dengan nilai $p_{\text {value }}=$ $0,629 \quad\left(p_{\text {value }}>0,05\right)$. Beberapa responden mengutarakan bahwa mereka baru mulai menggunakan kacamata. Hasil penelitian ini tidak sejalan dengan penelitian yang dilakukan oleh Valentina (2012) yang mengemukakan bahwa terdapat hubungan antara penggunaan kacamata dengan keluhan CVS pada mahasiswa jurusan ilmu computer $(\rho$-value $=0,043)(11)$.

Pengguna kacamata menunjukkan keluhan yang signifikan pada penelitian di Malaysia. Hasil yang sama dilaporkan oleh Reddy yang meneliti hubungan penggunaan kacamata dengan kejadian keluhan pada penderita CVS adalah signifikan dibandingkan dengan responden yang tidak menggunakan kacamata(13).

Dari hasil riset yang dilakukan National Institute of Occupational Safety and Health (NIOSH) bahwa penggunaan komputer terlalu lama dapat menimbulkan peningkatan stress yang lebih tinggi daripada pekerja lain. NIOSH juga menunjukkan, hampir 88\% dari seluruh pengguna komputer mengalami Computer Vision Syndrome (CVS), yaitu suatu kondisi yang terjadi karena terlalu lama memfokuskan mata ke layar komputer lebih dari empat jam sehari(6).

Hasil analisis statistik menunjukkan bahwa ada hubungan antara pengunaan komputer secara terus-menerus dengan kejadian CVS dengan nilai $p_{\text {value }}=0,000\left(p_{\text {value }}<0,05\right)$. Persentasi responden yang mengalami CVS pada responden yang bekerja $\geq 4$ jam lebih besar $(82,6 \%)$ dari pada yang tidak mengalami CVS. Hasil penelitian ini sejalan dengan penelitian yang dilakukan oleh Nopriadi (2019) yang menemukan hubungan antara lama bekerja (lama penggunaan computer) dengan CVS ( $\rho$-value $=0,000$ ). Nopriadi juga mengemukakan bahwa penggunaan computer $\geq 4$ jam sehari 9 kali lebih berisiko menyebabkan CVS pada karyawan Bank RK Pekanbaru(14). Hasil penelitian ini juga sejalan dengan yang dikemukakan oleh Sya'ban (2014) bahwa ada hubungan durasi lama paparan dengan gejala keluhan kelelahan mata $(\rho$-value $=0,000)$. Menurut penelitian ini hal ini dapat terjadi karena otot mata yang dipaksa bekerja secara terus menerus sehingga mengalami ketegangan otot dan menyebabkan kelelahan mata(15).

Lama istirahat dalam penelitian ini adalah lamanya istirahat mata selama minimal sepuluh menit setelah bekerja satu jam di depan layar computer. Frekuensi istirahat setelah menggunakan komputer terbukti menambah kenyamanan dan merelaksasikan daya akomodasi mata. Melakukan 

sejahtera kendari

istirahat kecil dengan frekuensi 5-10 menit lebih baik daripada isirahat panjang setiap 2-3 jam dari penggunaan komputer.Setidaknya sepuluh 10 menit selama kerja komputer satu jam terus menerus dikaitkan dengan CVS dan ini merupakan prediktor yang signifikan untuk CVS bila faktor lain dikendalikan. Aturan yang paling banyak digunakan sekarang adalah aturan 20/20/20 yaitu setelah bekerja selama 20 menit, sebaiknya mengalihkan pandangan dari monitor dengan melihat obyek yang jauh sekitar jarak 20 feet (6 meter) selama 20 detik(10)

Berdasarkan penelitian ini, hasil analisis statistik menunjukkan bahwa ada hubungan antara lama istirahat dengan kejadian CVS dengan nilai $p_{\text {value }}=0,004 \quad\left(p_{\text {value }}<0,05\right)$. Dalam penelitian ini, responden yang lama waktu istirahatnya adalah $<10$ menit lebih banyak mengalami CVS disbanding dengan yang lama istirahatnya $\geq 10$ menit. Hasil ini sejalan dengan hasil penelitian yang dikemukakan oleh Azkadina (2012), lama istirahat berhubungan secara signifikan dengan kejadian CVS. Pekerja pengguna komputer yang menyempatkan istirahat selama kurang dari 10 menit beresiko menderita CVS sebesar tiga belas setengah kali lipat dibandingkan dengan pekerja pengguna komputer yang menyempatkan istirahat selama lebih dari atau sama dengan 10 menit.

Frekuensi istirahat setelah menggunakan komputer terbukti menambah kenyamanan dan merelaksasikan daya akomodasi mata. Melakukan istirahat kecil dengan frekuensi 5-10 menit lebih baik daripada isirahat panjang setiap 2-3 jam dari penggunaan komputer.8,6 Hal ini serupa dengan penelitian di Malaysia tahun 2011 bahwa istirahat (setidaknya sepuluh 10 menit selama kerja komputer satu jam terus menerus) dikaitkan dengan CVS dan ini merupakan prediktor yang signifikan untuk CVS bila faktor lain dikendalikan(13).

Tidak ada batasan pasti tentang jarak monitor dan masih banyak faktor lain yang mempengaruhinya seperti besar monitor, namun menurut OSHA disebutkan bahwa jarak mata terhadap layar monitor yang baik adalah adalah 1824 inch inch atau 46-61 cm, sedangkan jarak ideal yaitu 20 inch atau sekitar 50,80 cm . Penyebab utama terjadinya kelelahan mata yaitu jarak mata yang terlalu dekat dengan monitor, sehingga mata dipaksa bekerja untuk melihat dari jarak yang cukup dekat dalam jangka waktu yang cukup lama, sedangkan fungsi mata sendiri sebenarnya tidak dikhususkan untuk melihat dari jarak dekat(15).

Berdasarkan tabel 2, proporsi responden berdasarkan jarak pandang dibagi menjadi dua kelompok, kategori $\geq 50 \mathrm{~cm}$ dan $<50 \mathrm{~cm}$. Terdapat 11 responden $(61,1 \%)$ mengalami CVS dan 7 responden $(38,9 \%)$ yang tidak mengalami CVS. Responden yang memiliki jarak pandang $\geq 50 \mathrm{~cm}$ mengalami CVS sebanyak 11 responden $(61,1 \%)$ dan 7 responden (38,9\%) yang tidak mengalami CVS.

Hasil uji chi square dengan tingkat kepercayaan 95\% $(p=0,05)$ diperoleh nilai $p_{\text {value }}=$ $1,000 \quad\left(p_{\text {value }}>0,05\right)$ dengan demikian dapat disimpulkan bahwa tidak terdapat hubungan antara jarak penglihatan dengan kejadian CVS pada pegawai di PT.Media Kita Sejahtera Kendari tahun 2019. Hal ini dapat terjadi karena berbagai factor, seperti lamanya penggunaan computer. Semakin lama seseorang menatap layar computer, maka dapat menyebabkan keluhan CVS terjadi baik itu pada responden yang melakukan jarak lebih atau kurang dari $50 \mathrm{~cm}$ terhadap monitor. Mata terfokus berjamjam dengan layar monitor sehingga menyebabkan mata menjadi lelah dan kering. Apalagi jika monitor yang digunakan memiliki tampilan yang terlalu suram atau kabur, terlalu silau, font huruf dan icon yang terlalu kecil, serta sulit untuk dibaca akan turut mempengaruhi terjadinya CVS(16).

Hasil penelitian ini sejalan dengan penelitian yang dilakukan oleh Putri (2018) yang menyebutkan bahwa tidak terdapat hubungan antara jarak monitor dengan keluhan kelelahan mata pada pengguna computer $(\rho$-value $=0,499)(17)$. Demikian pula hasil temuan yang ditemukan oleh Sya'ban (2014) yang menemukan bahwa tidak ada hubungan antara jarak monitor dengan keluhan kelelahan mata ( $\rho$-value $=0,346)(15)$.

\section{KESIMPULAN DAN SARAN}

Adapun kesimpulan dari hasil penelitian ini adalah ada hubungan antara lama penggunaan komputer dan lama istirahat dengan kejadian CVS pada pegawai pengguna komputer di PT. Media Kita Sejahtera Kendari.Tidak ada hubungan antara jenis kelamin, penggunaan kacamata, jarak mata dengan kejadian CVS pada pegawai pengguna komputer di PT. Media Kita Sejahtera Kendari. Saran penelitian ini adalah bagi pegawai pengguna komputer sebaiknya setiap 20 menit bekerja di depan komputer 
untuk istirahat paling tidak 20 detik dengan melihat obyek atau benda yang jaraknya sekitar 20 kaki untuk mencegah terjadinya CVS. Untuk peneliti lainnya agar dapat meneliti variabel lain yang berpengaruh terhadap CVS ini seperti variabel usia, ukuran obyek pada layar monitor, lama penggunaan VDT (termasuk tablet), tampilan layar monitor, jenis kegiatan responden, dan sebagainya.

\section{DAFTAR PUSTAKA}

1. Febrianti S. JIM FKEP Vol III No . 32018 Gejala Computer Vision Syndrome Pada Mahasiswa Keperawatan. 2018;III(3):201-7.

2. Fitriani S, Yasnani, Pratiwi AD. Faktor yang Berhubungan dengan Kelelahan Mata Pada Pekerja Las Listrik di Kecamatan Poasia Kota Kendri Tahun 2018. J Ilm Mhs Kesehat Masy [Internet]. 2019;4(1):1-6. Available from: http:/ / ojs.uho.ac.id/index.php/JIMKESMAS/a rticle/view/5795/4238

3. Rosenfield M. Computer vision syndrome: A review of ocular causes and potential treatments. Ophthalmic Physiol Opt. 2011;31(5):502-15.

4. Kementerian Kesehatan RI. InfoDatin Pusat Data Dan Informasi Kementrian Kesehatan RI Situasi Gangguan Penglihatan dan Kebutaan. 2014;1-12.

5. Darmaliputra K, Dharmadi M. Gambaran Faktor Risiko Individual Terhadap Kejadian Computer Vision Syndrome Pada Mahasiswa Jurusan Teknologi Informasi Universitas Udayana Tahun 2015. E-JURNAL Med VOL 8 NO1,Januari, 2019. 2019;8(1):95-102.

6. Permana MA, Koesyanto, Mardiana. Faktor yang Berhubungan dengan Keluhan Computer Vision Syndrome (CVS) pada Pekerja Rental Komputer di Wilayah UNNES. Unnes J Public Heal. 2015;4(3):48-57.

7. Nourmayanti D. Faktor-faktor yang Berhubungan dengan Keluhan Kelelahan Mata pada Pekerja Pengguna Komputer di Corporate Customer Care Center (C4) PT> Telekomunikasi Indonesia, Tbk Tahun 2009. Universitas Islam Negeri Syarif Hidayatullah Jakarta. Universitas Islam Negeri Syarif Hidayatullah Jakarta; 2010.

8. Sugarinda M, Allamsyah Z. Identifikasi Interaksi Manusia dan Komputer Berbasis Computer Vision Syndrome pada Unit Refinary Central Control Room. Teknoin [Internet]. 2017;23(1):6372. Available from: http:/ / repositorio.unan.edu.ni/2986/1/5624.pd f

9. Fradisha. Hubungan Durasi Penggunaan Komputer dengan Computer Vision Syndrome pada Karyawan Bank Sinarmas Jakarta. Nexus Kedokt Komunitas. 2017;6(1):50-61.
10. Azkadina A, Julianti H, Pramono D. Hubungan Antara Faktor Risiko Individual Dan Komputer Terhadap Kejadian Computer Vision Syndrome. J Kedokt Diponegoro. 2012;1(1):137662.

11. Valentina DCD, Yusran M, Wahyudo R, Himayani R. Faktor Risiko Sindrom Penglihatan Komputer pada Mahasiswa Jurusan Ilmu Komputer Fakultas Matematika dan Ilmu Pengetahuan Alam Universitas Lampung. JIMKI. 2019;7(2):29-37.

12. Anggraini Y. Faktor-faktor yang Berhubungan dengan Terjadinya Keluhan Computer Vision Syndrome (CVS) pada Operator Komputer PT. Bank Kalbar Kantor Pusat Tahun 2012 [Internet]. Universitas Tanjungpura. Universitas Tanjungpura; 2013. Available from: http://www.mendeley.com/research/geologyvolcanic-history-eruptive-style-yakedakevolcano-group-centraljapan/\%0Ahttps://doi.org/10.1016/j.actatropic a.2019.02.002\%0Ahttps://doi.org/10.1016/j.acta tropica.2018.07.028\%0Ahttp://dx.doi.org/10.10 16/j.ijppaw.201

13. Sari FTA, Himayani R. Faktor Risiko Terjadinya Computer Vision Syndrome Risk Factors Occurrence of Computer Vision Syndrome. 2018;7(28):278-82.

14. Nopriadi, Pratiwi Y, Leonita E, Tresnanengsih E. Faktor yang Berhubungan dengan Kejadian Computer Vision Syndrome pada Karyawan Bank Factors Associated with the Incidence of Computer Vision Syndrome in. J MKMI. 2019;15(2):111-9.

15. Sya'ban AR, Riski IMR. Faktor-Faktor Yang Berhubungan Dengan Gejala Kelelahan Mata pada Karyawan Pengguna Komputer PT. Grapari Telkomsel Kota Kendari. Proseding Seminar Bisinis \& Teknologi. 2014;754-68.

16. Setiawan D. Analisiskelelahan Mata Pekerja Sebelum Dan Sesudah Bekerja Pada Intensitas Penerangan Dibawah Standar Di Ruangan Office Pt. Buma Jobsite Adaro. 2010;1-71. Available from: http:/ / eprints.uns.ac.id/4752/1/1432112082010 02501.pdf

17. Putri DW, Mulyono. Hubungan Jarak Monitor, Durasi Penggunaan Komputer, Tampilan Layar Monitor, dan Pencahayaan dengan Keluhan Kelelahan Mata. Indones J Occup Saf Heal. 2018;7(1):1-10. 